\section{A Rare Cause of Abdominal Pain and Fever of Unknown Origin: Takayasu Arteritis}

\author{
Nadir Görülen Karın Ağrısı ve Nedeni Bilinmeyen \\ Ateş Sebebi: Takayasu Arteriti
}

\author{
Özlem Üzüm ๑ \\ Muhammed Ali Kanık ๑ \\ Kader Vardı $\odot$ \\ Yeliz Pekçevik ๑ \\ Kayı Eliaçık $\odot$ \\ Belde Kasap Demir ๑
}

\begin{abstract}
Fever of unknown origin has three most common etiologic categories in children including infectious diseases, connective tissue diseases, and neoplasms. Takayasu arteritis is a chronic vasculitis involving the large vessels, which generally presents with clinical features of vascular sequelae such as abdominal pain, hypertension, headaches and fever. In this article, we are presenting a 11 year-old girl admitted with fever lasting for one month and abdominal pain. Her physical examination and biochemical parameters were all within normal limits except for fever, abdominal pain and elevated acute phase reactant. Exclusion of infectious diseases, neoplasms and juvenile idiopatic arthritis, systemic lupus erythematosus; and demonstration of increased wall thickness in superior mesenteric artery and bilateral carotid arteries, established the diagnosis of Takayasu arteritis. It has been emphasized that fever of unknown origin and abdominal pain are atypical clinical manifestations of Takayasu arteritis, and early imaging including carotid Doppler ultrasonography may aid in the establishment of diagnosis of Takayasu arteritis in children.
\end{abstract}

Keywords: Abdominal pain, Doppler ultrasonography, fever of unknown origin, Takayasu arteritis

Öz

Nedeni bilinmeyen ateşin, çocuklarda en yaygın üç nedeni; enfeksiyöz hastalıklar, bağ dokusu hastalıkları ve malignitelerdir. Takayasu arteriti genellikle abdominal ağrı, hipertansiyon, baş ağrısı ve ateş gibi vasküler sekellerin klinik özellikleri ile seyreden, kronik büyük damar vaskülitidir. Bu olguda, bir ay boyunca ateş ve karın ağrısı şikayeti olan 11 yaşında bir kız çocuğu sunulmuştur. Olgunun fizik muayene ve biyokimyasal parametreleri; ateş, karın ağrısı ve yüksek akut faz reaktanı dışında normal sınırlarda saptanmıştır. Enfeksiyöz hastalıklar, malignite ve juvenil idiyopatik artrit ile sistemik lupus eritematozusun dışlanması; süperior mezenterik arter ve bilateral karotis arterlerde artmış duvar kalınlığının gösterilmesi ile Takayasu arteriti tanısı konulmuştur. Bu olguda, nedeni bilinmeyen ateş ve abdominal ağrının Takayasu arteritinin atipik klinik belirtileri olduğu ve erken dönemde karotis doppler ultrasonografi gibi görüntüleme yöntemleri kullanmanın tanıya yardımcı olabileceği vurgulanmıştır.

Anahtar kelimeler: Karın ağrısı, doppler ultrasonografi, nedeni bilinmeyen ateş, Takayasu arteriti
Alındığı tarih: 06.07.2018

Kabul tarihi: 16.08.2018

Online Yayın tarihi: 14.03.2019

Belde Kasap Demir İzmir Katip Çelebi Üniversitesi Tıp Fakültesi, Çocuk Nefroloji ve Romatoloji Bilim Dalı, İzmir, Türkiye beldekasap@gmail.com ORCiD: 0000-0002-5456-3509

Ö. Üzüm 0000-0003-3297-7476

K. Vardı 0000-0002-9690-9045

K. Eliaçık 0000-0001-9529-9719

SBÜ Tepecik EAH,

Çocuk Sağlığı ve Hastalıkları Kliniği, izmir, Türkiye

M. A. Kanık 0000-0003-3304-0992 izmir Katip Çelebi Üniv. Tıp Fak. Çocuk Sağlığı ve Hastalıkları, izmir, Türkiye

Y. Pekçevik 0000-0003-1421-3376 SBÜ Tepecik EAH, Radyoloji Anabilim Dalı, izmir, Türkiye

\section{INTRODUCTION}

Fever of unknown origin (FUO) is defined in children as fever $>38.3^{\circ} \mathrm{C}\left(101^{\circ} \mathrm{F}\right)$ at least once per day for $\geq 8$ days with no apparent diagnosis after initial outpatient or hospital evaluation that includes a detailed history, thorough physical examination, and initial laboratory assessment ${ }^{(1)}$. However, TA which presents with FUO is a rare presentation in children. In the literature, a four-year-old case with fever and decreased pulse rate diagnosed via computed tomog- raphy angiography and a seven-month-old girl with fever, irritability, high acute phase indices diagnosed with coronary artery, thoracic and abdominal aorta abnormalities mimicking Kawasaki disease have been reported as the etiological factors for FUO ${ }^{(6,7)}$. TA is a chronic vasculitis involving the large vessels. At diagnosis, ischemic symptoms are usually related to the affected vessels ${ }^{(2)}$. In this case report, we describe an 11-year-old girl diagnosed with TA in order to emphasize that this vasculitis should be considered in patients examined for FUO. 


\section{CASE REPORT}

An 11-year-old girl presented with fever persisting for one month despite antibiotic treatment for 14 days and periumbilical pain for a week. She had lost 10 kilograms within the last two months.

On admission, her body weight percentile was under 3, while her height was between 25th and 50th percentiles. Her body temperature was $38,4^{\circ} \mathrm{C}$ and pulse rate was well palpated at regular rhythm on both arms. No bruit was audible on the neck, chest or abdomen and blood pressure was 115/75 $\mathrm{mmHg}(<95 \mathrm{p} / 95 \mathrm{p})$ in the right arm, 110/70 $\mathrm{mmHg}$ $(<95 p / 95 p)$ in the left arm. There was no pathologic finding in the systemic evaluation except the abdominal tenderness. All the biochemical examinations including immunoglobulin levels and complements were within normal limits. C-reactive protein was $14.9 \mathrm{mg} / \mathrm{dL}$ and erythrocyte sedimentation rate was $140 \mathrm{~mm} / \mathrm{h}$. Blood and urine cultures and viral serological tests for hepatitis $B, C$, Human immunodeficiency virus, Epstein-Barr virus, cytomegalovirus all yielded negative results. To determine the cause of fever, chest X-ray, abdominal ultrasonography (US), echocardiography and ophthalmologic examination were performed, but all were unremarkable.. Autoimmune antibodies or tumor markers failed to reveal the cause of fever. No additional features were detected in peripheral smear or bone marrow examination. The patient's fever, abdominal pain and elevated acute phase reactants persisted for 14 days after admission. After exclusion of infectious diseases, malignancy, systemic lupus erythematosus (SLE) and systemic juvenile idiopathic arthritis (JIA), and the other types of vasculitis were considered in the differential diagnosis.

Because of abdominal pain and fever, branches of the abdominal aorta and renal arteries were evaluated with Doppler US to exclude polyarteritis nodosa. Thickening of vessel walls was observed in the proximal 4-5 cm segment of the superior mesenteric artery (SMA). Due to thickening of SMA walls in addition to fever and abdominal pain, carotid Doppler-US was performed on suspicion of TA. The carotid Doppler-US showed a thickening in the aorta and the left carotid artery wall. Whole-body magnetic resonance angiography was performed which showed diffuse thinning in the right main carotid artery, left main carotid artery and left internal carotid artery (Figure 1).

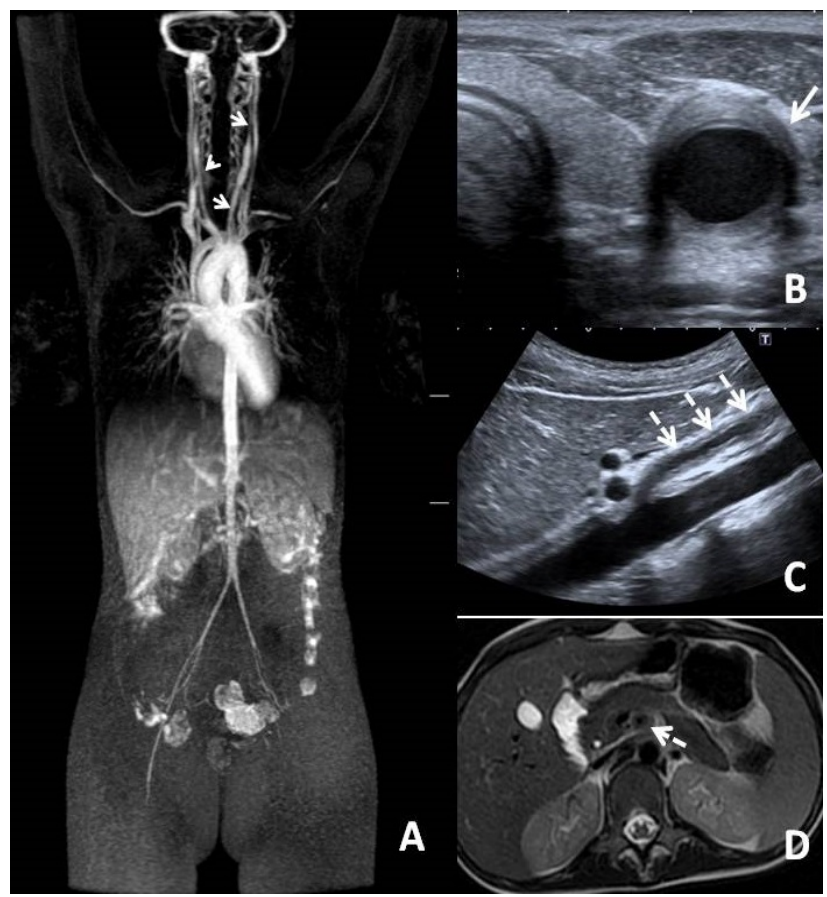

Figure 1. A) Whole-body MR angiography, diffuse thinning in the right main carotid artery (arrowhead), left main carotid artery and left internal carotid artery (arrows) is presented in maximum intensity projection image. B) Carotid ultrasonography shows left main carotid artery (arrow), C) Abdominal ultrasonography shows superior mesenteric artery (cut arrows) D) Abdomen MR shows diffuse thickening on T2-weighted axial section and superior mesenteric artery (cut arrow) wall.

The case was diagnosed with TA based on the findings of fever, abdominal pain, elevated levels of acute phase reactants, specific findings in DopplerUS and whole-body magnetic resonance angiography. Based on the angiographic findings, stent placement in SMA was discussed with interventional radiology team. They decided not to place a stent as the blood flow was normal. Corticosteroid and azathioprine treatments were initiated with acceptable response. As acute phase reactants began to rise while tapering corticosteroid dose, azathioprine was switched to methotrexate at a dose of $20 \mathrm{mg} / \mathrm{m}^{2}$ / week without any symptom and stable laboratory findings at 8th months of follow-up. 


\section{DISCUSSION}

Collagen tissue diseases are seen in $9 \%$ of the cases with FUO and most frequently with JIA and SLE (3). Takayasu arteritis is included in the etiology of FUO, which is more common in young women, and generally in the third and fourth decades of life ${ }^{(4,5)}$.

Takayasu arteritis is a chronic, autoimmune, granulomatous, inflammatory disease of the aorta and its major branches at their origin. Diagnosis of TA is challenging in the early phase of the disease ${ }^{(2,5)}$. In review of the literature, one-third of the patients with TA present with clinical features of vascular sequelae rather than active vasculitis such as abdominal pain, hypertension, headaches, fever, weight loss and vomiting ${ }^{(5,8)}$. Abdominal pain may result from ischemia or vascular pain due to the local inflammation ${ }^{(9)}$. Superior mesenteric artery involvement in TA is rare in children and only a few studies have been reported. One of them was a 7 year-old girl, with type III TA, in whom involvement in the thoracic descending aorta, abdominal aorta and/or renal arteries without any involvement in the branches of the aortic arch was seen ${ }^{(10,11)}$. If stenosis is the cause of abdominal pain in the mesentery, recent studies have highlighted percutaneous angioplasty as an effective method to treat stenosis triggered by primary vasculitis ${ }^{(12)}$. However, angioplasty was not required in our case.

Diagnostic criteria of TA, were established at the EULAR/Pediatric Rheumatology International Trials Organization (PRINTO)/PRES meeting in $2010{ }^{(13)}$. Mandatory criteria included angiographic abnormalities of the aorta and/or its branches, in addition to one of the following: pulse deficit or claudication, blood pressure discrepancy, bruits, hypertension, and increased acute phase reactants ${ }^{(14)}$. In our case, mandatory criteria were fulfilled in addition to high acute phase reactants. Doppler US was generally used in adult patients with TA and imagining of the common carotid and proximal subclavian arteries may show arterial wall thickening and luminal narrowing and may provide complementary information to magnetic resonance angiography about hemodynamics ${ }^{(15)}$. Our case suggested that carotid Doppler
US may also be helpful in the diagnosis of children with TA.

In conclusion, TA should be kept in mind as a rare cause of FUO and associated abdominal pain may be related to the involvement of SMA. High index of suspicion is needed and early Doppler-US and angiographic examinations should be considered for TA in children with FUO even in the absence of typical findings of TA including pulselessness, hypertension, blood pressure discrepancy between four extremities.

\section{REFERENCES}

1. Chien YL, Huang FL, Huang CM, Chen PY. Clinical approach to fever of unknown origin in children. J Microbiol Immunol Infect. 2017;50:893-8. https://doi.org/10.1016/j.jmii.2015.08.007

2. Aypar E, Celebi-Tayfur A, Keser M, Odabaş D, Ozaltin F, Paksoy $Y$, et al. Takayasu arteritis in a 4-year-old girl: case report and brief overview of the pediatric literature. Turk J Pediatr. 2012;54:536-9.

3. Kierzkowska B, Lipinska J, Baranska D, lewiadomska-Jarosik K, Biernacka-Zielińska M, Stańczyk J, et al. Takayasu's arteritis mimicking Kawasaki disease in 7-month-old infant, successfully treated with glucocorticosteroids and intravenous immunoglobulins. Rheumatol Int. 2012;32:3655-9. https://doi.org/10.1007/s00296-010-1518-y

4. Melamed E, Rosner I, Aslan K, Angel D. Back pain as the presenting manifestation of Takayasu arteritis. Isr Med Assoc J. 2010;12:507-8.

5. Palazzi DL. Fever of unknown origin in children: Evaluation. Kaplan SL, Sundel R, Drutz JE(ed). Uptodate. Last updated 29.03.2017. https://www.uptodate.com/contents/Fever-ofunknown-origin-in-children: Evaluation (Last access 22.05.2018)

6. Ozen S, Ruperto N, Dillon MJ, Bagga A, Barron K, Davin JC. EULAR/PReS endorsed consensus criteria for the classification of childhood vasculitides. Ann Rheum Dis. 2006;65:93641.

https://doi.org/10.1136/ard.2005.046300

7. Brunner J, Feldman BM, Tyrrell PN, Kuemmerle-Deschner JB, ZimmerhackI LB, Gassner I, et al. Takayasu arteritis in children and adolescents. Rheumatology 2010;49:1806-14. https://doi.org/10.1093/rheumatology/keq167

8. Wu H, Xu L, Liu Y, Zou Y, Qin F, Song L, et al. Clinical Manifestations and Longterm Outcome for Patients with Takayasu. J Rheumatol. 2014;41:2439-46. https://doi.org/10.3899/jrheum.140664

9. Sase Y, Morita Y, Sakuta T, Satoh M, Sasaki T, Kashihara N. Abdominal pain as the initial presentation of Takayasu arteritid. Mod Rheumatol. 2008;18:496-8. https://doi.org/10.3109/s10165-008-0075-7

10. Mendiola Ramírez K, Portillo Rivera AC, Galicia Reyes A, García Montes JA, Maldonado Velázquez Mdel R, Faugier Fuentes E. Type III Takayasu's arteritis in a pediatric patient. Case report and review of the literature. Reumatología Clínica 2012;8:216-9. https://doi.org/10.1016/j.reuma.2011.11.008 
11. Lacombe M. Renal and aortic involvement in Takayasu's disease. Bull Acad Natl Med. 2007;191:549-66.

12. Barros de Lima LY, Christopoulos GB, Braga VM, Nemézio ME, Souza AP, Rêgo AC. Treatment of mesenteric angina in patients with Takayasu's arteritis. Rev Bras Reumatol. 2011;51:188-95.

13. Ozen S, Pistorio A, lusan SM, Bakkaloğlu A, Herlin T, Brik R, et al. (2010) EULAR/PRINTO/PRES criteria for HenochSchonleinpurpura, childhood polyarteritisnodosa, childhood Wegener's granulomatosis and childhood Takayasu arteritis: Part II: final classification criteria. Ann Rheum Dis. 2010;
69:798-806.

https://doi.org/10.1136/ard.2009.116657

14. Mathew AJ, Goel R, Kumar S, Anda D. Childhood-onset Takayasu arteritis: an update J Rheumatol 2016;19:116-26.

15. Merkel PA. Clinical features and diagnosis of Takayasu arteritis. Matteson EL, Ramirez Curtis M(ed). Uptodate 05.06. 2017.

https://www.uptodate.com/contents/clinical-features-anddiagnosis-of-takayasu-arteritis?source=history_widget (Last access 22.05.2018) 